\title{
ANALISIS PERSETUJUAN ORANG TUA TERHADAP RENCANA PEMBELAJARAN TATAP MUKA TERBATAS DI SMK SANTA MARIA JAKARTA
}

\author{
${ }^{1}$ Nevly Wisano Powa, ${ }^{2}$ Witarsa Tambunan, ${ }^{3}$ Mesta Limbong \\ 1,2,3 Magister Administrasi Pendidikan PPs-UKI, Jakarta, Indonesia \\ e-mail: witarsa.oke@gmail.com, mesta.limbong@uki.ac.id
}

\begin{tabular}{l|l|l} 
Received : Mei, 2021 & Accepted : Mei, 2021 & Published : Juli, 2021
\end{tabular}

\begin{abstract}
Learning from home activities or also called distance learning carried out by utilizing technology was allegedly led to several negative impacts for students. The government then decided to impose limited face-to-face learning, one of which was parental consent. The purpose of this study was to analyze parental consent to the limited face-to-face learning plan at SMK Santa Maria Jakarta. The method used is descriptive method by distributing simple surveys to parents and a causal approach with fault tree, goal tree, and alternative tree analysis. The subjects of this study were all parents of students of SMK Santa Maria Jakarta as many as 356 respondents. The results of this study were most of the parents agreed with the implementation of limited face-to-face learning at SMK Santa Maria Jakarta.
\end{abstract}

Keywords: consent, face-to-face, learning, parents

\begin{abstract}
Abstrak
Kegiatan belajar dari rumah atau disebut juga pembelajaran jarak jauh (PJJ) dilakukan dengan memanfaatkan teknologi disinyalir memunculkan beberapa dampak negatif bagi peserta didik. Pemerintah kemudian menetapkan untuk memberlakukan Pembelajaran Tatap Muka (PTM) dengan syarat-syarat yang ketat yaitu salah satunya persetujuan orang tua. Tujuan penelitian ini adalah untuk menganalisis persetujuan orang tua terhadap rencana pemelajaran tatap muka terbatas di SMK Santa Maria Jakarta. Metode yang digunakan adalah metode deskriptif dengan menyebarkan survei sederhana kepada orang tua dan pendekatan sebab-akibat melalui analisis pohon masalah, pohon sasaran, dan pohon alternatif. Subjek penelitian ini adalah seluruh orang tua siswa SMK Santa Maria Jakarta sebanyak 356 responden. Hasil penelitian ini adalah sebagian besar orang tua setuju dengan pelaksanaan pembelajaran tatap muka terbatas di SMK Santa Maria Jakarta.
\end{abstract}

Kata Kunci: persetujan, orang tua, pembelajaran, tatap muka

\footnotetext{
Citation: Powa, N. W., Tambunan, W., \& Limbong, M. (2021). ANALISIS PERSETUJUAN ORANG TUA TERHADAP RENCANA PEMBELAJARAN TATAP MUKA TERBATAS DI SMK SANTA MARIA JAKARTA. Jurnal Manajemen Pendidikan, 10(2), 100-111. Retrieved from http://ejournal.uki.ac.id/index.php/imp/article/view/3274
} 


\section{PENDAHULUAN}

Di awal pandemi di bulan Maret tahun 2020, Kemendikbud melalui surat edaran nomor 4 tahun 2020 mengeluarkan pelaksanaan kebijakan pendidikan dalam masa darurat penyebaran korona virus disease. Kebijakan tersebut merupakan langkah strategis yang diambil di masa darurat covid dengan tetap sejalan dengan visi misi dan tujuan pendidikan, salah satunya adalah penerapan sistem Belajar Dari Rumah (BDR) atau disebut juga pembelajaran jarak jauh (PJJ). Evaluasi pembelajaran daring dari kemendikbud menemukan bahwa bahwa semakin lama pembelajaran tatap muka tidak terjadi semakin memberikan dampak negatif bagi peserta didik. Beberapa dampak yang dapat terjadi adalah (Kemendikbud, 2020): (a) Ancaman putus sekolah: anak terpaksa harus bekerja untuk membantu keuangan keluarga. Orang tua berpandangan bahwa sekolah tidak berperan dalam proses pengajaran jika tidak dilakukan secara tatap muka. (b) Hambatan pertumbuhan dan perkembangan: perbedaan perolehan kualitas yang terjadi selama periode PJJ menyebabkan kesenjangan kinerja akademik siswa.Selain itu turunnya partisipasi Pendidikan Anak Usia Dini sehingga kehilangan tumbuh kembang. Hilangnya pembelajaran secara berkepanjangan (learning loss) berisiko terhadap pembelajaran jangka panjang, termasuk perkembangan kognitif dan karakter. (c) Tekanan psikososial dan kekerasan dalam rumah tangga: minimnya interaksi ditambah sulitnya PJJ dapat menyebabkan stress pada anak. Selain itu tanpa sekolah, banyak anak terjebak di kekerasan rumah tangga tanpa terdeteksi oleh guru.

Dari hasil evaluasi tersebut, pemerintah mengeluarkan mendorong pelaksanaan pembelajaran tatap muka (PTM) terbatas sebagai langkah untuk mengembalikan kompetensi yang "hilang" selama masa pembelajaran daring. Pembelajaran tatap muka terbatas yang hendak dilaksanakan disekolah wajib memenuhi beberapa syarat utama antara lain: mendapat persetujuan dari pemerintah daerah setempat, menyediakan sarana penerapan protokol kesehatan, kapastias kelas maksimum 50\%, dan yang paling penting adalah persetujuan orang tua. Pada kebijakan yang dikeluarkan kemendikbud, menyebutkan bahwa jika orang tua tidak mengizinkan anaknya mengikuti pembelajaran tatap muka terbatas maka sekolah tetap harus memberikan pembelajaran bagi mereka secara daring. Dari deskripsi tersebut ini dapat dikatakan bahwa persetujuan orang tua menjadi kunci terlaksananya pembelajaran tatap muka di sekolah.

Proses pembelajaran jarak jauh di Sekolah Menengah Kejuruan (SMK) dinilai kurang efektif karena ciri khas SMK dengan pengembangan keterampilan sangat sulit dilakukan tanpa proses tatap muka secara langsung. Dari hasil penelitian Rachmat \& Krisnadi (2020) yang berjudul Analisis Efektifitas Pembelajaran Daring (Online) Untuk Siswa SMK Negeri 8 Kota Tangerang Pada Saat Pandemi Covid 19, menemukan bahwa pembelajaran daring untuk siswa SMK Negeri 8 Kota Tangerang kurang efektif dan siswa kurang paham dengan pembelajaran yang diberikan guru melalui pembelajaran daring. Berdasarkan penjabaran di atas, peneliti tertarik melakukan analisis mengenai persetujuan orang tua terhadap persiapan pembelajaran tatap muka terbatas di SMK Santa Maria Jakarta. Penelitian ini akan membahas mengapa persetujuan orang tua penting, serta bagaimana proses SMK Santa Maria mendapatkan persetujuan orang tua untuk anak mereka bisa mengikuti pembelajaran tatap muka terbatas.

Pembelajaran Tatap Muka Terbatas

Menurut Anggrawan (2019) pembelajaran tatap muka merupakan pembelajaran di kelas yang mengandalkan kehadiran pengajar untuk mengajar. Pada pembelajaran tatap muka siswa terlibat dalam komunikasi secara langsung pada lingkungan fisik. Nissa \& Haryanto (2020) menyebutkan bahwa Pembelajaran tatap muka merupakan cara pembelajaran klasikal dimana guru dan siswa berkomunikasi secara tatap muka di dalam ruangan atau forum yang sama. Pembelajaran ini memerlukan kehadiran guru dan siswa pada suatu tempat nyata (bukan virtual). Berdasarkan deskripsi di atas, maka pembelajaran tatap muka adalah suatu proses pembelajaran yang dilakukan dengan komunikasi antar guru murid secara langsung dalam suatu tempat tanpa adanya perantara media virtual. Pembelajaran tatap muka pada masa pandemi menjadi suatu pembelajaran yang 
sangat jarang dilakukan karena mempertimbangkan penularan virus Covid-19 sehingga pembelajaran tatap muka diganti dengan pembelajaran daring (online).

Kemendikbud mendorong mempercepat pelaksanaan pembelajaran tatap muka terbatas, yaitu pembelajaran tatap muka yang dilakukan dengan tetap memberlakukan protokol kesehatan (Kemendikbud, 2021). Pada tahun ajaran 2021/2022, pemerintah mewajibkan lembaga pendidikan untuk menyediakan (1) pembelajaran tatap muka terbatas melalui penerapan protokol kesehatan, dan (2) pembelajaran jarak jauh. Orang tua dipersilakan untuk memilih pembelajaran tatap muka terbatas atau melanjutkan pembelajaran jarak jauh untuk anak-anak mereka. Beberapa syarat yang harus dipenuhi oleh satuan pendidikan dalam pelaksanaan pembelajaran tatap muka terbatas diantaranya sebagai berikut.

1. Satuan pendidikan wajib memenuhi checklist sebelum memulai pelaksanaan pembelajaran tatap muka terbatas.

2. Pembelajaran tatap muka terbatas dikombinasikan dengan pembelajaran jarak jauh untuk memenuhi protokol kesehatan.

3. Sekalipun satuan pendidikan mulai melakukan pembelajaran tatap muka terbatas, orang tua / wali dapat memutuskan untuk memutuskan anak mereka terus belajar jarak jauh.

4. Pengawasan pembelajaran di Lembaga pendidikan dilakukan oleh pemerintah pusat, dan pemerintah daerah.

5. Apabila berdasarkan hasil pengawasan dan/atau kasus terkonfirmasi COVID-19, maka pemerintah pusat dan daerah wajib menangani kasus tersebut dan menghentikan pembelajaran tatap muka di satuan pendidikan..

6. Jika pemerintah pusat memiliki kebijakan untuk mencegah dan mengendalikan penyebaran COVID-19, pembelajaran tatap muka terbatas dapat dihentikan sementara sesuai periode kebijakan.

Protokol kesehatan yang ketat wajib dilaksanakan oleh seluruh warga satuan pendidikan. Pelaksanaan protokol kesahatan di tingkat SMA/SMK sesuai dengan ketentuan yang tertera pada tabel berikut sesuai dengan arahan Kemendikbud (2021). 


\begin{tabular}{|c|c|c|}
\hline Perihal & $\begin{array}{c}\text { Masa Transisi (2 bulan } \\
\text { pertama) }\end{array}$ & Masa kebiasaan baru \\
\hline Kondisi Kelas & \multicolumn{2}{|c|}{$\begin{array}{l}\text { jaga jarak minimal } 1,5 \text { meter dan maksimal } 18 \text { siswa per } \\
\text { kelas. }\end{array}$} \\
\hline $\begin{array}{lr}\text { Jumlah hari } & \text { dan jam } \\
\text { pembelajaran } & \text { tatap muka } \\
\text { terbatas } & \text { dengan } \\
\text { pembagian } & \text { rombongan } \\
\text { belajar (shiff) } & \end{array}$ & $\begin{array}{l}\text { Ditentukan oleh satuan } \\
\text { mengutamakan kesehatan da } \\
\text { pendidikan. }\end{array}$ & $\begin{array}{l}\text { pendidikan dengan tetap } \\
\text { In keselamatan warga satuan }\end{array}$ \\
\hline $\begin{array}{l}\text { Perilaku wajib di } \\
\text { lingkungan } \\
\text { pendidikan }\end{array}$ & $\begin{array}{l}\text { - Menggunakan masker } 31 \text { a } \\
\text { - Cuci tangan pakai } \\
\text { handsanitizer } \\
\text { - Melakukan physical dista } \\
\text { - Menerapkan etika batuk d } \\
\text { - Sehat dan jika mengidap } \\
\text { harus dalam kondisi terko } \\
\text { - Tidak memiliki gejala CO } \\
\text { serumah dengan warga sa }\end{array}$ & $\begin{array}{l}\text { apis sesuai ketentuan } \\
\text { sabun atau menggunakan } \\
\text { mcing } \\
\text { lan bersin } \\
\text { penyakit penyerta (comorbid) } \\
\text { ntrol. } \\
\text { VID-19, termasuk orang yang } \\
\text { tuan pendidikan. }\end{array}$ \\
\hline Kantin & $\begin{array}{l}\text { Tidak diperbolehkan. Warga } \\
\text { sekolah dianjurukan } \\
\text { membawa makanan bergizi } \\
\text { seimbang. }\end{array}$ & $\begin{array}{l}\text { Boleh beroperasi dengan } \\
\text { tetap } \quad \text { memberlakukan } \\
\text { protokol kesehatan. }\end{array}$ \\
\hline $\begin{array}{l}\text { Kegiatan Olahraga dan } \\
\text { Ekstrakurikuler }\end{array}$ & Tidak diperbolehkan. & $\begin{array}{l}\text { Diperbolehkan dengan tetap } \\
\text { memberlakukan protokol } \\
\text { kesehatan. }\end{array}$ \\
\hline $\begin{array}{lr}\text { Kegiatan } & \text { Selain } \\
\text { Pembelajaran } & \text { di } \\
\text { Lingkungan } & \text { Satuan } \\
\text { Pendidikan } & \end{array}$ & Tidak diperbolehkan. & $\begin{array}{l}\text { Diperbolehkan dengan tetap } \\
\text { menjaga protokol kesehatan. }\end{array}$ \\
\hline
\end{tabular}

Tabel 1: Protokol Kesehatan Selama PTM (Sumber: Kemendikbud, 2021)

Persetujuan Orang Tua

Pendidikan dalam keluarga adalah dasar bagi perkembangan anak. Orang tua memiliki peran penting dan utama dalam pendidikan anaknya. Oleh karena itu diperlukan partisipasi orang tua dalam proses pendidikan anak. Diadha (2015) mengatakan bahwa bahwa partisipasi orang tua dalam pendidikan anak merupakan berbagai kegiatan bersama yang dilakukan oleh orang tua dan guru di rumah dan sekolah dengan tujuan untuk memaksimalkan perkembangan dan kesejahteraan pendidikan anak di sekolah. Sementara itu menurut Lilawati (2020) lingkungan terdekat bagi anak untuk menerima pendidikan adalah lingkungan terdekat bagi orang tua dan kehidupannya, yang sangat besar pengaruhnya terhadap pertumbuhan dan perkembangan anak. Dengan kata lain orang tua menjadi penanggungjawab utama dalam pendidikan anaknya.

Persetujuan atau dalam Bahasa Inggris disebut Consent menurut kamus Meriam Webster (https://www.merriam-webster.com/dictionary/consent) adalah "compliance in or approval of what is done or proposed by another". Terjemahan secara bebas dapat diartikan sebagai "kepatuhan atau persetujuan atas apa yang dilakukan atau diusulkan oleh orang lain". Consent dilakukan oleh seseorang secara sadar terhadap suatu hal dengan memahami risiko yang telah disampaikan. Berdasarkan penjabaran di atas dapat disimpulkan bahwa persetujuan orang tua adalah suatu proses secara sadar dari orang tua siswa sebagai pendidik utama, dalam mematuhi hal yang diusulkan oleh pihak lain. Persetujuan orang tua menjadi dasar dalam pengambilan keputusan terhadap pelayanan pendidikan anak di sekolah. Dalam kaitannya dengan pembelajaran tatap muka terbatas selama masa pandemi, persetujuan orang tua menjadi komponen penting yang menentukan siswa bisa dilayani secara tatap muka atau dengan pembelajaran jarak jauh. 


\section{METODE PENELITIAN}

Penelitian ini menggunakan metode deskriptif, yaitu penelitian yang dilakukan dengan cara mendeskripsikan dan menginterpretasikan objek menurut keberadaan objek tersebut tanpa memanipulasi variabel penelitian (Hermawan, 2019). Penelitian deskriptif ini bertujuan untuk memberikan gambaran akurat dari beberapa situasi. Bagian yang dijabarkan dalam deskriptif dengan menganalisa respon orang tua terhadap rencana pembelajaran tatap muka. Subjek penelitian ini adalah orang tua siswa SMK Santa Maria Jakarta berjumlah 356 responden.

Sementara itu pendekatan kausalitas adalah penyelidikan sebab-akibat. Untuk menentukan kausalitas, penting untuk mengamati perubahan variabel penelitian yang diduga menyebabkan perubahan variabel lain, kemudian mengukur perubahan variabel lain (Rina Hayati, 2020). Pendekatan sebab akibat pada penelitian ini dilakukan dengan menggunakan analisa pohon masalah, pohon sasaran, dan pohon alternatif. Analisa pohon masalah, sasaran, dan alternatif adalah suatu teknik mengidentifikasi masalah, tujuan, dan alternatif dengan menggambarkan hubungan sebab-akibat dari beberapa faktor-faktor yang saling terkait (Asmoko, 2012). Instrumen yang digunakan adalah kuisioner berbentuk Google Form yang disebarkan melalui WhatsApp Group orang tua siswa. Instrumen berisi penjabaran prosedur pelaksanaan tatap muka terbatas dan 2 pertanyaan persetujuan orang tua sebagai berikut.

\begin{tabular}{llll}
\hline Pertanyaan & \multicolumn{2}{l}{ Pilihan Respon } \\
\hline $\begin{array}{l}\text { Setujukah Bapak/Ibu dengan kebijakan Pemerintah untuk } \\
\text { Pembelajaran Tatap Muka Terbatas berdasarkan SKB 4 Menteri yang }\end{array}$ & $\begin{array}{l}\text { 1. } \\
\text { telah }\end{array}$ Tidak \\
\hline Apakah Batangani pada tanggal 30 Maret 2021 lalu? & & \\
Pembelajaran Tatap MENGIJINKAN putra/i-nya untuk mengikuti & $1 . \quad$ Ya \\
PRODUKTIF/PRAKTIK dan BERSEDIA mengikuti serta mematuhi & 2. Tidak \\
protokol kesehatan yang berlaku di SMK Santa Maria khususnya dan & & \\
Yayasan Pendidikan Nitya Bhakti pada umumnya?
\end{tabular}

Tabel 2: Pertanyaan Kuisioner Penelitian

Catatan: Pembelajaran tatap muka terbatas dilaksanakan untuk mata pelajaran kompetensi keahlian (produktif) praktik. Untuk non praktik tetap dilaksanakan dengan PJJ.

\section{HASIL DAN PEMBAHASAN}

Analisis Pohon Masalah

Mengacu pada Surat Keputusan Bersama (SKB) 4 menteri Maret 2021, pemerintah menargetkan untuk melakukan Pembelajaran Tatap Muka (PTM) mulai tahun pelajaran 2021/2022. Langkah ini diharapkan dapat menjadi jawaban atas permasalahan yang dihadapi selama pelaksanaan pembelajaran jarak jauh (PJJ). Pemberian izin pelaksanaan PTM tentunya mengacu ketentuan berdasarkan SKB 4 menteri yaitu diantaranya sekolah wajib menyusun Prosedur Operasional Standar (POS) sehubungan dengan penerapan protokol kesehatan, pelaksanaan dilakukan dengan sistem shift, kapasitas ruang kelas terisi maksimal 50\%, menyediakan fasilitas yang menujang penerapan protokol kesehatan, dan yang paling penting adalah persetujuan orang tua. Hubungan sebab-akibat dari masalah ini dapat dilihat pada pohon masalah berikut. 


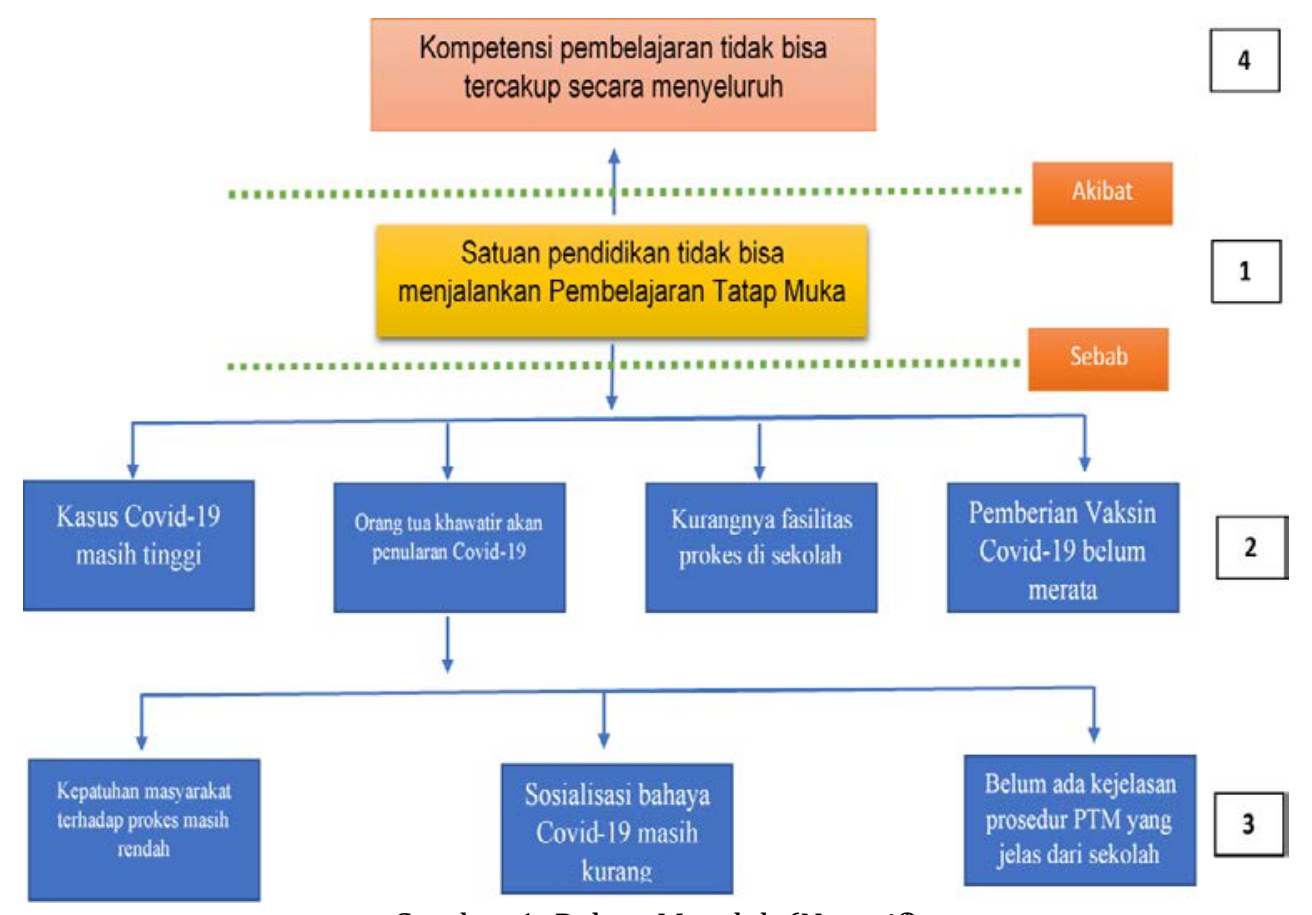

Gambar 1: Pohon Masalah (Negatif)

Berdasarkan gambar pohon masalah, permasalah utama yang terjadi adalah satuan pendidikan tidak bisa menjalankan pembelajaran tatap muka. Hal ini disebabkan oleh beberapa faktor seperti kasus Covid-19 yang masih tergolong tinggi, kurangnya fasilitas penunjang penerapan protocol kesehatan di sekolah, pemberian vaksin masih belum merata, dan yang diangkat menjadi penyebab utama adalah orang tua masih khawatir terhadap penularan Covid-19 kepada anak mereka. Kesehatan menjadi prioritas bagi setiap orang tua, membuat para orang tua merasa khawatir jika anak mereka memulai pembelajaran tatap muka di sekolah. Hal ini sesuai dengan hasil penelitian Meghani et al. (2021) yang menemukan bahwa hampir sepertiga orang tua di Amerika Serikat keberatan untuk mengembalikan anak-anak mereka ke sekolah meskipun PJJ yang dilakukan mengalami banyak tantangan. Mereka masih belum merasa aman mengizinkan anak mereka mengikuti pembelajaran tatap muka karena melihat tingkat penyebaran kasus Covid-19 yang tinggi dan juga sekolah belum memberikan informasi akurat terkait praktik keamanan dan penanganan terhadap Covid-19.

Kekhawatiran orang tua terhadap risiko penularan Covid-19 tentunya beralasan yang masuk akal. Beberapa penyebabnya antara lain:

a. Tingkat kepatuhan masyarakat terhadap protokol kesehatan masih sangat rendah. Hal ini sesuai dengan hasil penelitian dari Simanjuntak, Napitupulu, Wele, \& Yanie (2020) yang menemukan bahwa untuk sebanyak $80 \%$ yang lebih patuh menerapkan protokol kesehatan adalah individu berusia diatas 60 tahun. Sementara anak-anak usia sekolah dan orang dewasa masih sering lalai dalam penerapan protokol kesehatan seperti menggunakan masker, dan mencuci tangan.

b. Sosialisasi bahaya Covid-19 masih kurang sehingga banyak masyarakat masih meremehkannya.

c. Satuan pendidikan belum memberikan kejelasan prosedur pembelajaran tatap muka.

d. Karena faktor-faktor yang menyebabkan satuan pendidikan tidak bisa menjalankan pembelajaran tatap muka seperti yang sudah disebutkan di atas, mengakibatkan kompetensi pembelajaran tidak tercakup secara menyeluruh. Pembelajaran jarak jauh yang sudah dilakukan memberikan hambatan bagi para peserta didik untuk mempelajari kompetensi secara menyeluruh karena keterbatasan PJJ. Kompetensi yang dimaksud adalah pengetahuan, keterampilan, dan sikap baik sosial maupun spiritual. Dengan tidak 
terlaksananya pembelajaran tatap muka, maka kompetensi siswa yang juga hilang selama PJJ tidak bisa dikembalikan secara maksimal.

Analisis Pohon Sasaran

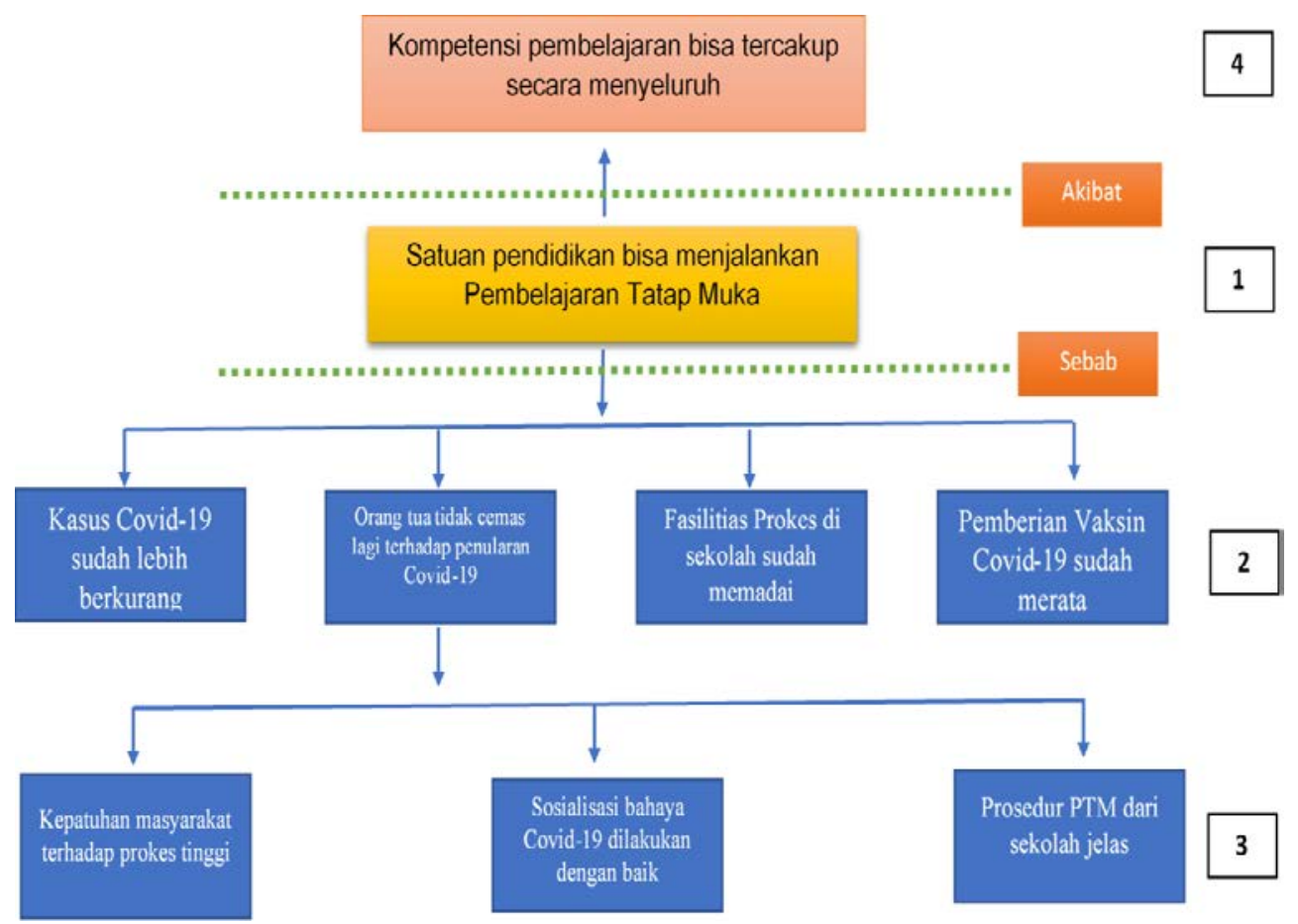

Gambar 2: Pohon Sarasan (Positif)

Berdasarkan pohon sasaran pada Gambar 2 terlihat bahwa sasaran utamanya adalah satuan pendidikan dapat menjalankan pembelajaran tatap muka. Hal ini bisa terjadi jika kasus Covid-19 sudah lebih berkurang, sarana dan prasarana protokol Kesehatan di sekolah sudah memadai, vaksin Covid-19 sudah merata khususnya bagi guru, dan orang tua tidak cemas lagi terhadap penularan Covid-19. Faktor penyebab utama yang menjadi sorotan adalah orang tua tidak cemas lagi terhadap penularan Covid-19. Poin ini sangat penting untuk pembukaan sekolah tatap muka karena siswa dan orang tua menjadi stakeholder utama bagi sekolah. Faktor-faktor yang bisa menyebabkan berkurangnya kecemasan orang tua terhadap penularan Covid-19 adalah sebagai berikut:

a. Tingkat kepatuhan masyarakat terhadap penerapan protokol kesehatan sudah meningkat. Variabel yang memberikan pengaruh nyata terhadap kepatuhan masyarakat terhadap protocol kesehatan covid-19 diantaranya yaitu usia, pendidikan, pengetahuan, sikap, dan motivasi (Afrianti \& Rahmiati, 2021). Dengan kondisi seperti ini diharapkan masyarakat usia sekolah lebih sadar dalam penggunaan masker yang benar, mencuci tangan, dan menjaga jarak aman dengan sesama.

b. Sosialisasi bahaya Covid-19 dilakukan dengan baik melibatkan seluruh elemen masyarakat. Diharapkan masyarakat mendapatkan edukasi yang benar tentang Covid-19 ini dan menepiskan semua hoax yang beredar. Langkah ini sangat penting untuk meningkatkan awareness masyarakat terhadap Covid-19 dan penanganannya.

c. Prosedur pelaksanaan pembelajaran tatap muka sudah jelas. Proses ini membantu orang tua memahami bahwa anak mereka berada di tempat yang aman selama belajar di sekolah.

b. Dengan harapan bahwa pelaksanaan pembelajaran tatap muka dapat terlaksana di satuan pendidikan, akan mengakibatkan kompetensi pembelajaran dapat tercakup secara 
menyeluruh. Siswa diharapkan mendapatkan pembelajaran lebih maksimal selama proses pembelajaran tatap muka berlangsung.

Persiapan Pembelajaran Tatap Muka Terbatas Di SMK Santa Maria Jakarta

SMK Santa Maria dan Kampus Santa Maria melakukan usaha maksimal dalam mempersiapkan proses pembelajaran tatap muka. Sebagai bagian dalam mengurangi kekhawatiran orang tua, SMK Santa Maria sudah menyiapkan fasilitas dan prosedur untuk penerapan protokol kesehatan.

Sesuai dengan anjuran pemerintah, SMK Santa Maria melakukan hal-hal berikut dalam persiapan pelaksanaan pembelajaran tatap muka terbatas yaitu:

a. Menyusun prosedur pelaksanaan protokol kesehatan seperti pengukuran suhu tubuh, penggunaan masker, mencuci tangan, dan menjaga jarak. Prosedur ini tertempel bagianbagian yang mudah terlihat mulai dari pintu masuk sampai ke area kampus Santa Maria.

b. Membentuk tim satuan tugas (satgas) mulai dari yayasan, hingga sampai ke unit-unit satuan pendidikan. Satgas berkoordinasi dengan kepala sekolah dan semua warga satuan pendidikan untuk mendukung penerapan protokol kesehatan, serta penanganan kasus Covid-19 yang muncul di sekolah.

c. Menyiapkan sarana dan pra sarana penerapan protokol kesehatan seperti memperbanyak tempat cuci tangan, pengadaan hand sanitizer, memberikan penanda untuk jaga jarak.

d. Melakukan sosialisasi penerapan protokol kesehatan melalui media sosial.

e. Merumuskan jadwal dan pembagian ruangan kelas dengan kapasitas maksimum 50\% dari jumlah siswa per kelas.

f. Menyebarkan angket survei persetujuan orang tua terhadap pembelajaran tatap muka terbatas.

Analisis Hasil Kuisioner

Survey kesediaan pembelajaran tatap muka terbatas tahun pelajaran 2021/2022 di SMK Santa Maria menerima 356 responden di Google Form. Data profil responden dapat dilihat dari grafik berikut.
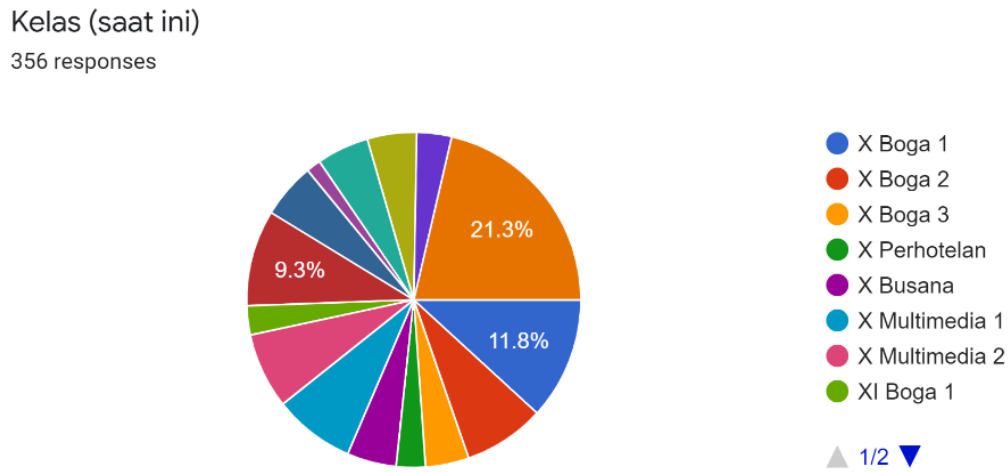

Gambar 3: Profil Responden

Dari Gambar 3 terlihat bahwa penyebaran responden berasal dari seluruh rombongan belajar di SMK Santa Maria Jakarta termasuk 21,3\% berasal dari orang tua peserta didik baru Tahun Pelajaran 2021/2022. Hasil survey pada pertanyaan pertama "Setujukah Bapak/Ibu dengan kebijakan Pemerintah untuk Pembelajaran Tatap Muka Terbatas berdasarkan SKB 4 Menteri yang telah ditandatangani pada tanggal 30 Maret 2021 lalu?" adalah seperti pada Gambar 4. Dari data di Gambar 4 terlihat bahwa 72,2\% (250 responden) orang tua setuju dengan kebijakan pembelajaran 
tatap muka terbatas dari pemerintah. Sebanyak 29,8\% (106 responden) orang tua tidak menyetujui mengenai kebijakan pembelajaran tatap muka terbatas.

Setujukah Bapak/lbu dengan kebijakan Pemerintah untuk Pembelajaran Tatap Muka Terbatas berdasarkan SKB 4 Menteri yang telah ditandatangani pada tanggal 30 Maret 2021 lalu? 356 responses

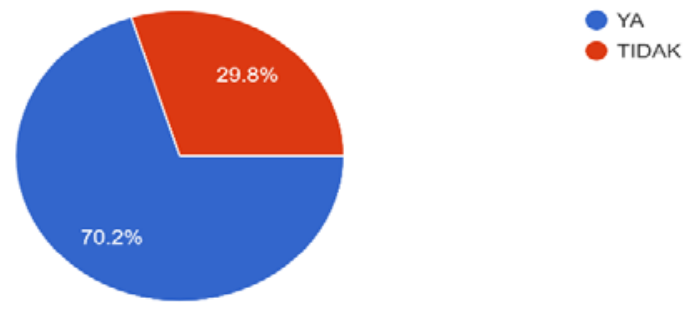

Apakah Bapak/lbu MENGIJINKAN putra/i-nya untuk mengikuti Pembelajaran Tatap Muka Terbatas untuk mata pelajaran PRODUKTIF/PRAKTIK dan BER...Yayasan Pendidikan Nitya Bhakti pada umumnya? 356 responses

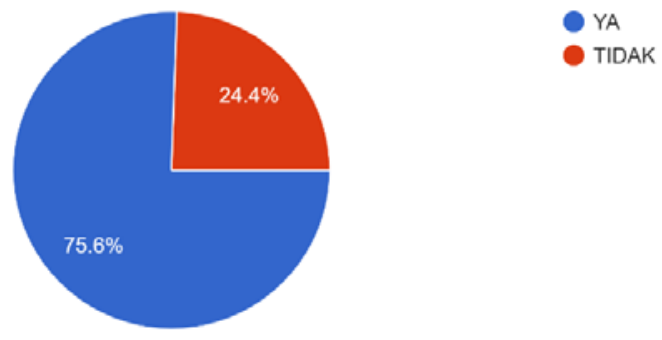

Gambar 5: Respon Pertanyaan Kedua

Hasil respon pertanyaan kedua "Apakah Bapak/Ibu MENGIJINKAN putra/i-nya untuk mengikuti Pembelajaran Tatap Muka Terbatas untuk mata pelajaran PRODUKTIF/PRAKTIK dan BERSEDIA mengikuti serta mematuhi protokol kesehatan yang berlaku di SMK Santa Maria khususnya dan Yayasan Pendidikan Nitya Bhakti pada umumnya?" terlihat pada Gambar 5. Berdasarkan data di atas terlihat bahwa 76,6\% (269 responden) orang tua setuju anak mereka mengikuti pembelajaran tatap muka terbatas khusus untuk mata pelajaran produktif. Dan $24,4 \%$ (87 responden) orang tua tidak setuju anak mereka mengikuti pembelajaran tatap muka terbatas dan tetap mengikuti pembelajaran jarak jauh pada mata pelajaran produktif.

Berdasarkan data di atas dapat disimpulkan bahwa sebagian besar orang tua setuju dan memahami risiko yang mungkin bisa terjadi dalam proses pembelajaran tatap muka terbatas. Hal ini dapat terjadi karena kekhawatiran orang tua siswa SMK Santa Maria Jakarta terhadap pembelajaran tatap muka mengingat bahwa SMK Santa Maria Jakarta sudah sangat siap dalam penerapan protokol kesehatan. Jika pembelajaran tatap muka terbatas di SMK Santa Maria bisa terlaksana, maka capaian kompetensi siswa bisa maksimal.

Analisis Pohon Alternatif 
Dari analisis pohon masalah, dan pohon sasaran dapat diilustrasikan alternatif-alternatif sebagai penyelesaian. Pohon alternatif dapat digambarkan berdasarkan Gambar 6.

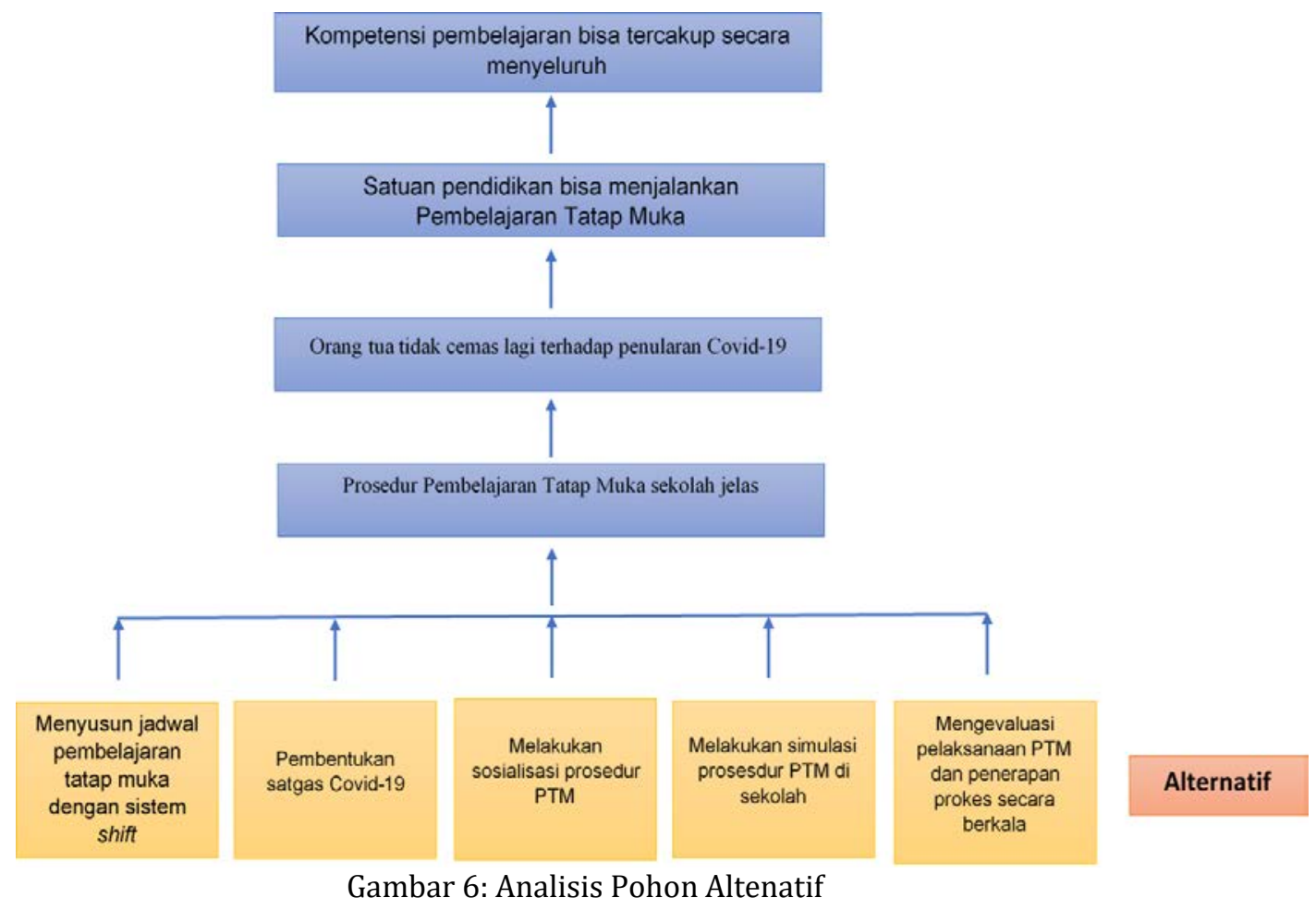

Dari ilustrasi pohon alternatif di atas terdapat 5 program yang bisa dilakukan untuk menciptakan kejelasan dalam prosedur pembelajaran tatap muka yaitu:

a. Menyusun jadwal pembelajaran tatap muka dengan sistem shift. Sistem ini memungkinkan terjadinya pengurangan kapasistas kelas pada waktu yang bersamaan sehingga terjadi physical distancing (Kemendikbud, 2021).

b. Pembentukan satuan tugas (satgas) penanganan Covid-19 di sekolah. Satgas Covid-19 ini akan berperan aktif menyusun program berkaitan dengan pencegahan Covid-19, memantau penerapan protokol kesehatan selama proses pembelajaran tatap muka berlangsung, mengevaluasi penerapan protokol kesehatan di sekolah, berkoordinasi dengan daerah dan staf puskemas terdekat, melakukan komunikasi kepada seluruh komunitas sekolah, dan menentukan pembukaan atau penutupan sekolah atau kelas.

c. Melakukan sosialisasi prosedur pelaksanaan pembelajaran tatap muka kepada seluruh komunitas sekolah secara bertahap. Sosialisasi dimulai dari guru dan staf, kemudian dilanjutkan kepada siswa dan orang tua. Langkah ini penting dilakukan sebelum memulai proses pembelajaran tatap muka agar pada saat pelaksanaannya dapat berjalan lancar.

d. Melakukan simulasi prosedur pembelajaran tatap muka di sekolah. Agar dapat memperoleh prediksi mengenai kejadian-kejadian yang mungkin terjadi saat pembelajaran tatap muka, para guru dan staf dengan koordinasi satgas Covid-19 sekolah diwajibkan melakukan simulasi. Mulai dari prosedur kedatangan, proses masuk kelas, istirahat, sampai pada kepulangan peserta didik. Proses simulasi kemudian dievaluasi untuk menjadi masukkan jika menemukan kendala-kendala saat kondisi nyata.

e. Mengevaluasi pelaksanaan pembelajaran tatap muka dan penerapan protokol kesehatan secara berkala. Tahapan ini menjadi acuan bagi pihak sekolah untuk melanjutkan pembelajaran tatap muka atau tidak. 
Jika lima alternatif di atas dapat terlaksana dengan maksimal maka dapat dikatakan bahwa satuan pendidikan sudah memiliki prosedur pembelajaran tatap muka yang jelas. Akibatnya adalah kekhawatiran orang tua terhadap penyebaran Covid-19 menurun dan kepercayan terhadap sekolah meningkat, sehingga sekolah dapat melaksanakan pembelajaran tatap muka dengan maksimal. Sehingga kompetensi yang diterima oleh siswa dapat tercakup secara menyeluruh.

Kedisiplinan dari semua komunitas sekolah menjadi kunci utama dalam penerapan protokol kesehatan. Selain itu peran aktif kepala sekolah sangat diperlukan dalam memastikan pembelajaran tatap muka terbatas berlangsung dengan aman. Langkah-langkah yang bisa dilakukan kepala sekolah adalah (Kemendikbud, 2021):

a. konsisten memberikan edukasi tentang penerapan protokol kesehatan dalam upaya membangun budaya disiplin,

b. memastikan seluruh pembelajaran tatap muka terbatas berlangsung sesuai protokol kesehatan.

c. menyiapkan satgas Covid-19 di sekolah.

d. diperlukan penanganan khusus. Jika ditemukan kasus terkonfirmasi Covid-19, pembelajaran tatap muka terbatas dapat ditutup sementara.

\section{KESIMPULAN}

Kesimpulan

Berdasarkan pembahasan dan analisis data ternyata kompetensi pembelajaran bisa tercakup secara menyeluruh karena satuan pendidikan bisa melakukan pembelajaran tatap muka terbatas. Hal ini disebabkan karena orang tua sudah tidak cemas dengan penyebaran Covid-19 serta memberikan persetujuan kepada anaknya. Persetujuan orang tua ini dikarenakan prosedur pembelajaran tatap muka terbatas yang diberikan oleh satuan pendidikan sudah sangat jelas.

Implikasi

SMK Santa Maria Jakarta sudah siap dalam melaksanakan pembelajaran tatap muka terbatas terlihat dari persiapan yang sudah sangat matang. Sebagian besar orang tua setuju dengan pembelajaran tatap muka terbatas, serta setuju anaknya mengikut pembelajaran tatap muka terbatas di sekolah. Oleh karena itu capaian kompetensi siswa khususnya pada mata pelajaran produktif dapat tercapai dengan maksimal.

Saran

Beberapa program yang bisa dilakukan untuk menciptakan kejelasan dalam prosedur pembelajaran tatap muka yaitu: (1) Menyusun jadwal pembelajaran tatap muka dengan sistem shift. (2) Pembentukan satuan tugas (satgas) penanganan Covid-19 di sekolah. (3) Melakukan sosialisasi prosedur pelaksanaan pembelajaran tatap muka kepada seluruh komunitas sekolah secara bertahap. (4) Melakukan simulasi prosedur pembelajaran tatap muka di sekolah. (5) Mengevaluasi pelaksanaan pembelajaran tatap muka dan penerapan protokol kesehatan secara berkala.

\section{DAFTAR PUSTAKA}

1. Afrianti, N., \& Rahmiati, C. (2021). Faktor-Faktor Yang Mempengaruhi Kepatuhan Masyarakat Terhadap Protokol Kesehatan Covid-19. Jurnal Ilmiah STIKES Kendal, 11(1), 113-124.

2. Anggrawan, A. (2019). Analisis Deskriptif Hasil Belajar Pembelajaran Tatap Muka dan Pembelajaran Online Menurut Gaya Belajar Mahasiswa. MATRIK : Jurnal Manajemen, Teknik Informatika dan Rekayasa Komputer, 18(2), 339-346. https://doi.org/10.30812/matrik.v18i2.411 
3. Asmoko, H. (2012). Memahami Analisis Pohon Masalah. In Balai Diklat Kepemimpinan.

4. Diadha, R. (2015). Keterlibatan Orang Tua Dalam Pendidikan Anak Usia Dini Di Taman KanakKanak. Edusentris, 2(1), 61. https://doi.org/10.17509/edusentris.v2i1.161

5. Hermawan, I. (2019). Metode Penelitian Pendidikan: Kuantitatif, Kualitatif, Dan Mixed Methode. Kuningan: Hidayatul Quran.

6. Kemendikbud. (2020). Pemerintah Daerah Diberikan Kewenangan Penuh Tentukan Izin Pembelajaran Tatap Muka Diambil $11 \quad$ Mei 2021, dari https://www.kemdikbud.go.id/main/blog/2020/11/pemerintah-daerah-diberikankewenangan-penuh-tentukan-izin-pembelajaran-tatap-muka

7. Kemendikbud. (2021). Keputusan Bersama Menteri Pendidikan Dan Kebudayaan, Menteri Agama, Menteri Kesehatan, dan Menterti Dalam Negeri Tentang Panduan Penyelenggaraan Pembelajaran Di Masa Pandemi Coronavirus Disease 2019 (Covid-19). Jakarta: Kemendikbud.

8. Lilawati, A. (2020). Peran Orang Tua dalam Mendukung Kegiatan Pembelajaran di Rumah pada Masa Pandemi. Jurnal Obsesi: Jurnal Pendidikan Anak Usia Dini, 5(1), 549. https://doi.org/10.31004/obsesi.v5i1.630

9. Meghani, A., Agarwal, S., Alexander, ;, Zapf, J., Edwards, J. G., Labrique, A., ... Gibson, D. (2021). Schooling amidst a pandemic: parents' perceptions about reopening schools and anticipated challenges during COVID-19. medRxiv, 2021.03.02.21252777. Diambil dari https://doi.org/10.1101/2021.03.02.21252777

10. Nissa, S. F., \& Haryanto, A. (2020). Implementasi Pembelajaran Tatap Muka Di Masa Pandemi Covid-19. Jurnal IKA PGSD (Ikatan Alumni PGSD) UNARS, 8(2), 402. https://doi.org/10.36841/pgsdunars.v8i2.840

11. Rachmat, A., \& Krisnadi, I. (2020). Analisis Efektifitas Pembelajaran Daring (Online) Untuk Siswa SMK Negeri 8 Kota Tangerang Pada Saat Pandemi Covid 19. Jurnal Pendidikan, 1(1), 1-7.

12. Rina Hayati. (2020). Pengertian Penelitian Kausal, Ciri, Kelebihan, Kekurangan, dan Contohnya. 29 Juni. Diambil dari https://penelitianilmiah.com/penelitian-kausal/

13. Simanjuntak, D. R., Napitupulu, T. M., Wele, A. M., \& Yanie, R. (2020). Gambaran Kepatuhan Masyarakat Menerapkan Protokol Kesehatan COVID-19 Di Tempat Umum Periode September 2020 di DKI Jakarta. Fakultas Kedokteran Universitas Kristen Indonesia, (September 2020). 